\title{
Spatial Structure and Productivity in U.S. Metropolitan Areas
}

\author{
Evert Meijers and Martijn Burger
}

Accepted and forthcoming in Environment and Planning A

\begin{tabular}{|l|l|}
\hline \multicolumn{2}{|l|}{ ERIM REPORT SERIES RESEARCH IN MANAGEMENT } \\
\hline ERIM Report Series reference number & ERS-2009-057-ORG \\
\hline Publication & December 2009 \\
\hline Number of pages & 44 \\
\hline Persistent paper URL & http://hdl.handle.net/1765/17431 \\
\hline Email address corresponding author & mburger@ese.eur.nl \\
\hline Address & Erasmus Research Institute of Management (ERIM) \\
& RSM Erasmus University / Erasmus School of Economics \\
& Erasmus Universiteit Rotterdam \\
& P.O.Box 1738 \\
& 3000 DR Rotterdam, The Netherlands \\
& Phone: + 31 10 408 1182 \\
& Fax: + 31 10 408 9640 \\
& Email: info@erim.eur.nl \\
& Internet: $\quad$ www.erim.eur.nl \\
\hline
\end{tabular}

Bibliographic data and classifications of all the ERIM reports are also available on the ERIM website: www.erim.eur.nl 


\section{ERASMUS RESEARCH INSTITUTE OF MANAGEMENT}

\section{REPORT SERIES}

\section{RESEARCH IN MANAGEMENT}

\begin{tabular}{|l|l|}
\hline ABSTRACT AND KEYWORDS \\
\hline Abstract & $\begin{array}{l}\text { Recent concepts as megaregions and polycentric urban regions emphasize that external } \\
\text { economies are not confined to a single urban core, but shared among a collection of close-by } \\
\text { and linked cities. However, empirical analyses of agglomeration and agglomeration externalities } \\
\text { so-far neglects the multicentric spatial organization of agglomeration and the possibility of } \\
\text { 'sharing' or 'borrowing' of size between cities. This paper takes up this empirical challenge by } \\
\text { analyzing how different spatial structures, in particular the monocentricity - polycentricity } \\
\text { dimension, affect the economic performance of U.S. metropolitan areas. OLS and 2SLS models } \\
\text { explaining labor productivity show that spatial structure matters. Polycentricity is associated with } \\
\text { higher labor productivity. This appears to justify suggestions that, compared to relatively } \\
\text { monocentric metropolitan areas, agglomeration diseconomies remain relatively limited in the } \\
\text { more polycentric metropolitan areas, while agglomeration externalities are indeed to some extent } \\
\text { shared among the cities in such an area. However, it was also found that a network of } \\
\text { geographically proximate smaller cities cannot provide a substitute for the urbanization } \\
\text { externalities of a single large city. }\end{array}$ \\
\hline Free Keywords & polycentricity, dispersion, labor productivity, urbanization externalities \\
\hline Availability & The ERIM Report Series is distributed through the following platforms: \\
Academic Repository at Erasmus University (DEAR), DEAR ERIM Series Portal \\
Social Science Research Network (SSRN), SSRN ERIM Series Webpage \\
Research Papers in Economics (REPEC), REPEC ERIM Series Webpage
\end{tabular}




\section{Spatial Structure and Productivity in U.S. Metropolitan Areas}

\section{E.J. (Evert) Meijers}

Delft University of Technology, OTB Research Institute for Housing, Urban and Mobility Studies. PO Box 5030, 2600 GA Delft, The Netherlands. E-mail:

e.j.meijers@tudelft.nl

(Corresponding author)

M.J. (Martijn) Burger

Erasmus University Rotterdam, Department of Applied Economics and ERIM. PO Box 1738, 3000 DR Rotterdam, The Netherlands. E-mail: mburger@ese.eur.nl. URL:

http://www.mjburger.net.

Abstract

Recent concepts as megaregions and polycentric urban regions emphasize that external economies are not confined to a single urban core, but shared among a collection of close-by and linked cities. However, empirical analyses of agglomeration and agglomeration externalities so-far neglects the multicentric spatial organization of agglomeration and the possibility of 'sharing' or 'borrowing' of size between cities. This paper takes up this empirical challenge by analyzing how different spatial structures, in particular the monocentricity - polycentricity dimension, affect the economic performance of U.S. metropolitan areas. OLS and 2SLS models explaining labor productivity show that spatial structure matters. Polycentricity is associated with higher labor productivity. This appears to justify suggestions that, compared to relatively monocentric metropolitan areas, agglomeration diseconomies remain relatively limited in the more polycentric metropolitan areas, while agglomeration externalities are indeed to some extent shared among the cities in such an area. However, it was also found that a network of geographically proximate smaller cities cannot provide a substitute for the urbanization externalities of a single large city.

Keywords: Polycentricity, Dispersion, Labor productivity, Urbanization externalities

\section{Acknowledgement}

Evert Meijers wishes to thank the funding provided by the Netherlands Organisation for Scientific Research (NWO). The paper has benefited from well thought-out comments by Nick Phelps as well as three anonymous reviewers, 


\section{Spatial Structure and Productivity in U.S. Metropolitan Areas}

\section{Introduction}

Slowly but steadily, the image of the city has changed dramatically over the last one and a half century. The industrial image of a city - as being composed of an urban core and a rural hinterland - has become increasingly obsolete. Advances in transport infrastructure and rising levels of car ownership have fuelled a process of decentralization and suburbanization, initially of people, but later followed by jobs (Boarnet, 1994). However, this trend does not stop with the establishment of new centers in the city or at its edges. We are also witnessing the 'fusion' of formerly relatively independent and distinct cities into wider metropolitan areas. Nowadays, what is 'urban' increasingly spreads out over a wider region, requiring us to think of the city as a regional phenomenon (Scott, 1988; Storper, 1997). This is reflected in the revival of the debate on city-regions (Parr, 2005) and in the conceptualisation of regionalised urban entities (Kloosterman and Musterd, 2001; Hall and Pain, 2006; Florida et al., 2008). In spatial terms, the spatial structure of such regions can be characterised as a series of towns 'physically separate but functionally networked, clustered around one or more larger cities' (Hall and Pain, 2006, 3), or 'integrated sets of cities and their surrounding suburban hinterlands' (Florida et al., 2008, 459). Therefore, the emerging spatial form of post-industrial urban regions is quintessentially polycentric (Hall, 2000; Kloosterman and Musterd, 2001; Phelps and Ozawa, 2003). 
Essential to this debate on such regionalised urban entities is the underlying idea that external economies are not confined to a well-defined single urban core, but, instead, are shared among a group of functionally linked settlements (Phelps and Ozawa, 2003; Sassen, 2007). The basic idea of polycentricity is that multiple centers or cities, and hence multiple sources of agglomeration economies, are colocated and also interact, given the widening geographical scale of economic and social processes (Van Oort et al., 2010). Such 'regionalisation' of urbanization externalities has been conceptualised and described by several scholars (Richardson, 1995; Coe and Townsend, 1998), thereby deploying terms such as 'urban network externalities' (Capello, 2000), 'spatial externality fields' (Phelps et al., 2001) or 'regional externalities' (Parr, 2002). Such concepts build on the concept of 'borrowed size', coined by Alonso (1973), who used it to explain why smaller cities that are part of a megalopolitan urban complex had much higher incomes than self-standing cities of similar size. According to Phelps and Ozawa (2003, 594), 'the idea of borrowed size suggests that today's examples of megalopolitan agglomeration are based predominantly on some combination of pecuniary and technological externalities open to service industries across a group of settlements, rather than the technological externalities available at the localised scale of discrete towns or cities.'

When external economies are increasingly conceptualised in relational terms (Gordon and McCann, 2000; Phelps and Ozawa, 2003; Johansson and Quigley, 2004; Burger et al., 2009), it would make sense to study agglomeration externalities at the scale of the regional urban system rather than the single city, as the interactions with nearby cities may also influence the presence of agglomeration externalities. However, such research is rather non-existent. It seems that empirical analysis of 
economic agglomeration does not correspond to the changes in the geographical scale at which agglomeration manifests itself (Phelps and Ozawa, 2003; Burger et al., 2010). In analysis, the shape of the urban system is most often simply taken for granted (Scott, 2000; Kloosterman and Musterd, 2001). In equilibrium approaches, the economic organisation of space is not a concern (see Corpataux and Crevoisier, 2007).

The principal objective of this paper is to provide some first steps to overcome the empirical deficit that characterises the current debate about the sharing of agglomeration externalities between a collection of more or less proximally located cities. Do cities actually borrow size from each other? Can a collection of close-by cities provide a substitute for the urbanization externalities of a single larger city? These key questions are at the heart of the worldwide policy debates on the geographical scale of agglomeration, be it the megaregions in the U.S. or Asia or the somewhat smaller - in spatial terms- polycentric urban regions that have become such a popular planning concept in Europe (see Meijers, 2005).

The approach developed in this paper to answer the question of whether cities borrow, or share, size, is to include the spatial structure of metropolitan areas into empirical analysis of agglomeration externalities. Building on previous work by Anas et al. (1998) and Lee and Gordon (2007), we will not limit ourselves to the monocentricity-polycentricity dimension, but also include a centralization-dispersion dimension. Labor productivity is used as a proxy for metropolitan performance. We extend existing production functions (notably Ciccone \& Hall, 1996) with spatial variables other than the commonly used indicators as size or average density. 
The remainder of this article is organised as follows. We synthesise the literature discussing the spatial structure of metropolitan areas in relation to their performance in Section 2, which results in three testable assumptions. Section 3 presents our measurements of the spatial structure of metropolitan areas. Section 4 continues with the model specification and other data used. Section 5 presents the estimation results. Section 6 concludes and discusses the implications of our findings.

\section{Urbanization, spatial structure and metropolitan performance}

Spatial structure tends to attract increasing interest from urban geographers and planners as it is believed to affect the economic performance, environmental sustainability and social well-being of places and their inhabitants. Clear examples are the 'new urbanism' and 'smart growth' movements in urban planning circles in the U.S. Although in regional science and urban economics there is a large empirical literature which links city characteristics to urban performance, often empirical work on agglomeration does not go beyond including average density or city size ('urbanization externalities') as a spatially relevant factor. However, neither density nor size reveals much about a region's spatial organization.

Indicators of the spatial organisation of metropolitan areas need to address two questions (Anas et al., 1998). First, how is the urban population spread over urban centers? Second, to what extent is the metropolitan population located in urban centers or dispersed? The first question refers to a monocentric-polycentric dimension, while the second question refers to a centralization-dispersion dimension. Below, we address the relationship of size, monocentricity-polycentricity and 
centralization-dispersion respectively with metropolitan performance, which results in three testable hypotheses.

\subsection{Size and urbanization externalities}

A large strand of empirical research in regional science and urban economics focuses on the benefits stemming from the size or density of the urban economy. As a general rule, these urbanization externalities can be regarded as external economies passed to firms as a result of savings from large-scale operation of the city as a whole. These benefits are uncontrollable and unregulable for a single firm and, above all, immobile or spatially constrained (Van Oort, 2004). Following Isard (1956), it is the availability of a large and multi-functional labor pool and the presence of a good infrastructure and public facilities in dense economic areas that are the sources of urbanization externalities. Relatively more urbanized areas are also more likely to accommodate universities, $R \& D$ laboratories, trade associations, and other knowledge-generating institutions. Moreover, the often diverse industry mix in an economically dense area increases the odds of interaction, generation, replication, modification and recombination of ideas and applications across different sectors (Van Oort, 2004) and protects a region from volatile demand (Frenken et al., 2007). Finally, the presence of a large internal market offers a larger degree of stability and lower transport costs (Siegel et al., 1995). However, a high degree of urbanization may also result in a dispersion of economic activities due to pollution, crime or high land and housing prices. In this respect, one can speak of urbanization diseconomies, which are assumed to be negatively related to metropolitan performance. We expect to confirm the strong positive relation between size and metropolitan performance, 
but our main interest lies with the monocentricity-polycentricity and centralizationdispersion dimensions of urban spatial structure.

\subsection{Monocentricity and polycentricity}

Whereas metropolitan size is linked to external economies to scale, monocentricity or polycentricity, and centralization or dispersion can be linked to some sort of external economies to structure. In the current debate on metropolitan spatial structure, the influence of monocentricity or its opposite, polycentricity, on the performance of metropolitan areas remains unclear due to a lack of empirical research, while this evidence is urgently needed (Lambooy, 1998; Kloosterman and Musterd, 2001; Parr, 2004; Turok and Bailey, 2004; Cheshire, 2006; Parr, 2008; Meijers, 2008a).

At the spatial scale of the metropolitan area, Lee and Gordon (2007) did not find that a polycentric or monocentric structure, measured by the subcenters' share of all center employment, does affect metropolitan population and employment growth. Still, it is generally brought forward that the advantage of polycentricity at the local level is that it comes with a lack of agglomeration disadvantages (see Fujita et al., 1997, Goffette-Nagot and Schmitt, 1999; Bertaud, 2004) such as fierce competition for land and workers, congestion, and pollution exposure.

Agglomeration disadvantages appear to be largely confined to the scale of individual cities within the metropolitan area (Parr, 2002) and evidence suggests that smaller cities have a greater endogenous capacity to keep these social, economic and environmental costs under control (Capello and Camagni, 2000). When, at the same time, the idea holds that agglomeration advantages are increasingly associated with 
a more regionalized spatial structure (Parr, 2002; Capello and Camagni, 2000; Sassen, 2007) as networks may substitute for agglomeration (Johansson and Quigley, 2004), then polycentricity will become an increasingly strong asset of metropolitan areas. So far, however, it remains untested that a polycentric spatial structure in metropolitan areas leads to successful economic development (Parr, 2008; Parr, 2004; Lambooy, 1998). Building on the idea that agglomeration advantages have 'regionalized' to a considerable extent, while disadvantages remain local issues, we hypothesize in this paper that a more polycentric urban structure has a direct and positive effect on metropolitan performance, as they may provide a better balance between agglomeration advantages and agglomeration disadvantages.

\section{Extent of regionalization of urbanization externalities}

Despite the theoretical consensus regarding the 'regionalization' of urban externalities, the extent to which such a 'regionalization' may take place in a polycentric spatial structure is highly questioned. According to Bailey and Turok (2001) the idea that the integration of separate cities results in agglomeration advantages comparable to similar-sized monocentric cities is 'rather simplistic'. Parr $(2004 ; 2008)$ points in this respect to the need for longer travel flows, longer commodity flows and less convenient flows of information in polycentric urban regions. Moreover, it should be noted that 'some of the advantages of urban size stem from the nature of the metropolitan environment, and are related to such factors as density, proximity, face-to-face contact, informal structures, unplanned interaction, etc.' (Parr, 2004, 236), and consequently hold less for polycentric urban regions. This is confirmed by a recent study (Meijers, 2008a) that showed that 
polycentric regions in the Netherlands had significantly less cultural, leisure and sports amenities than monocentric regions in which the urban population is concentrated in a single city. In this paper we test the hypothesis that polycentricity diminishes the effect of urbanization economies on labor productivity at the regional metropolitan scale.

\subsection{Centralization and dispersion}

A dispersed spatial structure refers to the situation in which a large part of the population is not living in centers but spread out across the territory in a nonconcentrated pattern. It is not necessarily similar to urban sprawl, as this is often equated with low-density residential development, whereas dispersion concerns the issue of whether this development is taking place in centers or not, leaving aside the question of density. Whether or not dispersion negatively influences urban performance is an unsolved issue and as far as it corresponds to urban sprawl even controversial. According to a 2000 Costs of Sprawl report (Transportation Research Board, 2002), dispersed low-density development consumes more land and infrastructure, provides fewer fiscal impacts, whilst increasing housing costs, personal travel costs and automobile dependence. Critics claim that spread out, dispersed development fulfills a widespread need for safe neighbourhoods, appreciating housing values, and unrestricted use of automobiles. Glaeser and Kahn (2004) stress the association of sprawl with significant improvements in quality of life. According to the 2000 Costs of Sprawl study, the alternative is a form of centralization that directs development to locations where it is more efficient to provide public services. This is referred to as 'smart growth'. In this study we will test 
the hypothesis that metropolitan areas that have a higher proportion of the population living in urban places, and hence, less dispersion, perform better in terms of labor productivity.

\section{Quantifying metropolitan spatial structure}

A prerequisite for testing the idea of whether urbanization economies are dependent on spatial structure is to quantify this regional spatial structure. Next to size, we distinguished two dimensions that effect spatial concentration. Here we discuss their exact measurement. The centralization-dispersion dimension refers to the extent to which population and employment is centralised in cities or dispersed over smaller non-urban places in the area in a non-centralised pattern. The monocentricitypolycentricity dimension reflects the extent to which urban population and employment is concentrated in one city or spread over multiple cities in the wider metropolitan area (see Figure 1). These two dimensions are quite similar to the two types of spatial concentration at the city-level discerned by Anas et al. (1998) in their classic essay on the urban spatial structure of cities (see also Lee and Gordon, 2007), although in terms of measurement we adopt them to the larger metropolitan area scale.

<Figure 1>

\subsection{Monocentricity versus polycentricity}


In the literature, one finds different interpretations of what makes a metropolitan area polycentric (Meijers, 2008b). Grossly speaking, there is an approach that defines polycentricity on the basis of urban morphology (see Kloosterman and Musterd, 2001; Parr, 2004), while another approach adds relational aspects to it in the sense that a metropolitan area can only be considered polycentric when the cities are strongly functionally linked, which is sometimes referred to as 'relational polycentricity' or 'functional polycentricity' (see for instance Hall and Pain, 2006; Green, 2007; De Goei et al., 2009). Here, we adhere to the first and least restrictive vision, thus studying the monocentricity-polycentricity dimension from a morphological perspective. It is important to note that polycentricity is not so much about the presence of multiple cities in a metropolitan area, but about the balance in the size distribution of these cities. The more even this balance and hence the lack of a strong hierarchy, the more polycentric (Kloosterman and Lambregts, 2001; Parr, 2004; Meijers, 2005).

The rank-size distribution of the regional urban system provides information on this hierarchy and is therefore a useful indication of the extent of mono- or polycentricity (Spiekermann and Wegener in Nordregio et al., 2004; Parr, 2004). Figure 2 presents the four largest incorporated places in two U.S. metropolitan areas and also the regression slope that best fits the distribution of their sizes. The flatter this slope is, the more polycentric the metropolitan area. Conversely, the steeper this slope is, the more monocentric the metropolitan area. In this example, San Antonio, TX, is obviously monocentric, while San Jose-San Francisco-Oakland, CA, is a clear example of a polycentric metropolitan area. 
$<$ Figure 2>

In this study we calculated the slope of the regression line of the rank-size distribution of incorporated places (cities) ${ }^{1}$ in each U.S. metropolitan area. Following Meijers (2008b) we did so for different numbers of incorporated places per metropolitan area (2, 3 and 4) and then calculated the average of these three scores. The slopes found were normally distributed, meaning that the majority of metropolitan areas in the US cannot be considered (very) monocentric nor (very) polycentric, but are somewhere in between those extremes on the same scale. It appears that only the most polycentric metropolitan areas can be considered polycentric urban regions in the way they are usually defined. ${ }^{2}$ Below we will refer to the position of a metropolitan area on this scale ranging from monocentric to polycentric as its' 'degree of polycentricity', simply because higher values mean that it is more polycentric. Otherwise, we could have equally chosen to term it the 'degree of monocentricity'.

The rank-size distribution does not provide information on the spread of cities over the metropolitan territory, but polycentricity is also about spatially distinct cities (Parr, 2004; Kloosterman and Lambregts, 2001). Therefore, we need to filter out regions that score polycentric in terms of the rank-size distribution, but in which the cities are part of the same contiguous built-up area. In the latter case, the term polycentric conurbation is more appropriate. If the two largest cities of a metropolitan area that scored polycentric belong to the same 'urban area', which is delineated by the US Census Bureau to encompass densely settled territory, we labelled these 'polycentric conurbations'. We did not include these polycentric 
conurbations in the analysis as it could be argued that these metropolitan areas, while scoring polycentrically, in fact resemble monocentric metropolitan areas more, the main difference being the presence of administrative boundaries dividing the built-up area (see Appendix A).

\subsection{Centralization versus dispersion}

The share of the central city in total metropolitan area population in the U.S. fell rapidly from almost $64 \%$ in 1930 to $38 \%$ in 2000 (Kim, 2007). The question then is where the majority of the metropolitan population is located; are they clustered in other urban centers or are they dispersed over the metropolitan territory in an uncentered way? In order to test the hypothesis that less centralization and thus more dispersion limits labor productivity, we scored each case study area on a centralization-dispersion axis, their position being dependent on the share of the metropolitan population that was not located in urban centers of at least 25,000 inhabitants in 2006.

Association of dimensions

Both dimensions are associated in the sense that more polycentric metropolitan areas tend to be characterised slightly more often by dispersion. But, as Table 1 displays, there are several exceptions to this 'rule'. For instance Midland-Odessa, TX, is the most polycentric metropolitan area, while it is also among the top 5 most centralised areas.

$<$ Table 1> 


\section{Model, data and estimation strategy}

\subsection{Model}

In regional science and urban economics, many studies have investigated the effect of urbanization externalities using aggregate production functions at the city level. Although different functional forms of the urban production exist, our point of departure is the models developed in Ciccone and Hall (1996) and Ciccone (2002), who use a Cobb-Douglas production function to assess the effect of agglomeration economies on localised labor productivity.

Consider the following production function of a metropolitan economy with production factors capital $(K)$, labor $(L)$, human capital $(H)$, materials or intermediate inputs $(M)$ and land $(N)$ in which a single good is produced that is a composite of all the outputs of all producers in that metropolitan area (1),

$Q=A K^{\kappa} L^{\lambda} H^{\varepsilon} M^{\mu} N^{v}$

in which $Q$ is the nominal output. In equation (1), A represents an efficiency parameter or vector of exogenous influences on the nominal output measuring Total Factor Productivity. Amongst others, the efficiency parameter $A$ here reflects the urbanization externalities and metropolitan spatial structure (the degree of polycentricity and of dispersion). Given constant returns to scale $(\chi+\lambda+\varepsilon+\mu+\nu=1)$, equation (1) can be rewritten as (2) 


$$
\left(\frac{Q}{L}\right)=A\left(\frac{K}{L}\right)^{\kappa}\left(\frac{H}{L}\right)^{\xi}\left(\frac{M}{L}\right)^{\mu}\left(\frac{N}{L}\right)^{v},
$$

in which the output per worker (labor productivity) is a function of the capital-labor ratio, human capital-labor ratio (or alternatively, education per worker), intermediate inputs-labor ratio, land-labor ratio, and the efficiency parameter A. By taking logarithms on both sides of equation (2), the multiplicative form can be converted into a linear stochastic form, to give the following testable equation (3):

$$
\ln \left(\frac{Q}{L}\right)=\theta_{0}+\kappa \ln \left(\frac{K}{L}\right)+\xi \ln \left(\frac{H}{L}\right)+\mu \ln \left(\frac{M}{L}\right)+\sigma \ln \left(\frac{N}{L}\right)+\sum_{j} \theta_{j+1}\left(\ln X_{j}\right)+r_{j}+\varepsilon
$$

, where equation (3) is augmented with a set of variables $X$ with parameters 9 , which are related to metropolitan size and spatial structure and enter the production function through a higher value of A (Fogarty and Garofolo, 1988; Broersma and Oosterhaven, 2009). Here, this set includes the size of the metropolitan population, the degree of polycentricity, and the degree of dispersion. Following Ciccone (2002) census region dummy variables $r_{j}$ are included to account for remaining differences in exogenous Total Factor Productivity which may moderate the relationship between agglomeration, spatial structure and labor productivity, such as relative differences in climate, price levels, and levels of technology across metropolitan areas. 


\subsection{Data and Variables}

To estimate our production function, data was gathered for metropolitan statistical areas (MSAs), but in the many cases in which these were part of a wider combined statistical area (CSA) we used this widest possible definition of U.S. metropolitan areas, which is largely based on commuting behavior (see Appendix A). The reason to principally focus on CSAs comes forward from the necessity to analyse the performance of cities in their wider spatial context and we wanted to avoid the monocentric perspective that underlies the MSA definition. For example, it was deemed necessary for this analysis to take the San Jose- San Francisco - Oakland CSA as a unit of analysis rather than the MSAs that make up this CSA separately. Data concerns those metropolitan areas located in continental U.S with a total population over 250,000 inhabitants in 2006.

Our dependent variable Labor Productivity is measured as the 2006 GDP in real dollars of a metropolitan area divided by the total number of jobs in the included sectors in that area in 2006. As our research underlies a market-based model and spatial externalities are most profound in sectors that lack exogenous endowments, agriculture, fishing, hunting, mining and public administration were excluded (see also Brülhart and Mathys 2008). In addition, no figures on self-employment were available. Data on GDP by metropolitan area and sector were obtained from the U.S. Department of Commerce's Bureau of Economic Analysis (BEA). Data on the number of jobs were provided by the Bureau of Labor Statistics (BLS) of the U.S. Department of Labor, and for individual sectors taken from the 2006 American Community Survey. The new BEA estimates enable a more direct measurement of labor productivity than previously possible, when many researchers used indirect proxies 
such as the mean annual wage or household income. Descriptive statistics are provided in Table 2. Note that corresponding specification (3), all non-dummy variables in our empirical analysis are log-transformed.

With respect to the factor inputs, the Capital-Labor Ratio within a metropolitan area was measured by linking the capital-labor ratio of broad sectors, as obtained from the Annual Survey of Manufacturers, to the industrial composition within the metropolitan area (based on a division into 15 sectors). Hence, the obtained value is a weighted average of the capital-labor ratio across sectors. Although this operationalization does not account for regional differences within sectors (e.g., capital intensity, level of technology and sub-sector specialization), it provides a reasonable proxy to the capital-labor ratio within metropolitan areas. The Land-Labor Ratio is defined as the average number of acres per worker within a metropolitan area. The human capital-labor ratio or average Education per Worker within a metropolitan area is obtained from the American Community Survey (2006) and measured as the percentage of the metropolitan population of 25 years and older with a bachelor's degree or higher. As our output variable is Gross Domestic Product (GDP), which equals the total production minus intermediate inputs, we do not take intermediate goods into consideration (see also Broersma and Oosterhaven, 2009).

However, the main variables of interest in our research are the indicators related to the urbanization externalities and spatial structure. Urbanization externalities are captured by the variable Metropolitan Size, which is measured as the size of the metropolitan population in 2006. With respect to urban spatial structure, we include both a metropolitan area's degree of Polycentricity and its degree of 
Dispersion in our model. Their measurement was discussed in section 3. Finally, dummy variables based on the census divisions are included, which reflect nine broad geographic regions in the United States (New England, Middle Atlantic, South Atlantic, East North Central, East South Central, West North Central, West South Central, Mountain and Pacific; see also Lee and Gordon, 2007). ${ }^{3}$ These dummies attempt to control for some of the unobserved heterogeneity across metropolitan areas, in particular differences in technology and price levels.

$<$ Table 2>

\subsection{Endogeneity and Two Stage Least Squares Estimation (TSLS)}

Although equation (3) can be estimated using conventional Ordinary Least Squares (OLS), this estimation technique does not account for the simultaneity between metropolitan size and structure and labor productivity. In the model specification, it is assumed that metropolitan size and spatial structure have an effect on metropolitan labor productivity. However, the causality of this relationship is far from clear. On the one hand, agglomeration is often associated with a number of benefits such as labor market pooling, accessibility to intermediate goods, knowledge spillovers, and proximity to consumers, which in turn would augment productivity. On the other hand, firms may also be attracted to economically dense areas because of the presence of higher productivity levels (Rosenthal and Strange, 2004). In other words, agglomeration can be regarded as both a cause and consequence of labor productivity. Likewise, metropolitan spatial structure may be regarded a consequence rather than a cause of labor productivity growth. High land and real 
estate prices in combination, driven by high levels of labor productivity in city centers, may disperse people and firms out of the main cities into the wider metropolitan area. In this case, it is not spatial structure that directs metropolitan performance, but metropolitan performance that directs spatial structure.

Not accounting for simultaneity can lead to inconsistent estimates as it violates one of the underlying assumptions of OLS, namely that the independent variables are uncorrelated with the disturbance term of the dependent variable. In other words, the independent variables should not be affected by the dependent variable. Probably the most common technique to deal with this (potential) simultaneity bias is to isolate the effect that runs from agglomeration and urban spatial structure to labor productivity by means of a two stage least squares (TSLS) estimation (see also, Ciccone and Hall, 1996; Ciccone, 2002; Combes et al., 2008). In order to do so, we need instruments, or variables that are correlated with the endogenous independent variables but not with the dependent variable. Hence, they should be 'relevant', but at the same time 'exogenous'. Based on Ciccone and Hall (1996), we used five historical variables that are not related to labor productivity today, as production 60-150 years ago was organised in a very different way than nowadays, but that did significantly contribute to today's metropolitan size and spatial structure:

1. The metropolitan population in 1950

2. The degree of polycentricity in 1950

3. The degree of dispersion in 1950

4. Presence or absence of a railroad in the metropolitan area in 1860 (Stover, 1961). 
5. Agricultural land use, measured as the density of employment in agriculture outside the urban areas.

The 1950 variables are constructed in exactly the same way as our 2006 variables and their inclusion as instrumental variables is obvious. With respect to our railroad variable, it is assumed that the presence or absence of railroads in 1860 was not driven by modern productivity differences (Ciccone and Hall, 1996), but are important in explaining agglomeration at the end of the $19^{\text {th }}$ century and the development of other places through suburbanization in the early $20^{\text {th }}$ century. Finally, the agricultural land use variable is used as an instrument of dispersion: more extensive agricultural land use outside the urban areas increases relative land rent as competition for land intensifies (Brueckner, 2001). This in turn, slows down the development of housing and offices outside the urban area compared to metropolitan areas in which non-urban land is relatively cheap. Agricultural land use is however not related to our dependent variable as this sector was excluded in the measurement of the labor productivity of metropolitan areas.

\section{Empirical Results}

\subsection{Testing for endogeneity of metropolitan size and spatial structure}

Although there may be a problem of recursive causality from a theoretical point of view, this does not necessarily mean that there is a problem from an econometric point of view (Combes et al., 2008). If indeed the independent variables of interest can be treated as exogenous, then OLS, which is a more efficient estimator, should 
be preferred over the TSLS estimator (Woolridge, 2006). In order to conduct such a test, the instruments need to fulfil two general conditions: they should be relevant (not weak) and valid (exogenous).

Table 3 shows the test results on the relevance and validity of the instruments as well as the endogeneity of metropolitan size and structure. The endogenous variables were tested both separately and simultaneously. In other words, we ran three regressions in which we instrumented metropolitan size, polycentricity or dispersion and one regression in which we instrumented the three variables simultaneously. We included more instruments than endogenous independent variables in each specification in order to conduct an overidentification test to assess the validity of the instruments. On the basis of the Anderson canonical correlation, Cragg-Donald F-statistic and Shea Partial $\mathrm{R}^{2}$ statistics, we can conclude that our instruments are relevant. ${ }^{4}$ With respect to testing the validity of the instruments, both the Sargan and Basmann test indicate that our instruments are valid. ${ }^{5}$

$<$ Table 3>

Finally, we tested whether the endogenous independent variables included are also econometrically endogenous. In this, the Wu-Hausman F-test and Durbin-WuHausman Chi-Square test assess the null-hypothesis that the instrumented variables are exogenous by comparing the TSLS estimates with the OLS estimates. From these tests it can be concluded that metropolitan spatial structure, defined by monocentricity-polycentricity and centralization-dispersion can be treated as exogenous. In line with Lee and Gordon (2007), this is not surprising because spatial 
restructuring can be considered a long-term process. However, for the specification in which metropolitan size is instrumented the Durbin-Wu-Hausman test rejects the hypothesis at a $5 \%$ confidence level $(p=0.021)$. The estimation of this equation using the OLS estimator would therefore not yield inconsistent results. Examining the specification with multiple endogenous regressors, we cannot reject the nullhypothesis that metropolitan size and metropolitan spatial structure are exogenous. As both the Wu-Hausman F-test and Durbin-Wu-Hausman Chi-Square test indicate that there is no evidence for an endogenous relationship between labor productivity and metropolitan size and structure, OLS estimation should be used, given the fact that our instruments are relevant and valid and OLS more efficient. However, we test for robustness of our results by comparing the OLS estimates with the estimates from the TSLS specification in which only metropolitan size is treated as endogenous.

\subsection{Labor productivity, urbanization externalities and spatial structure}

Model 1 in Table 4 shows the results of the OLS estimation of metropolitan size and spatial structure on labor productivity, controlling for capital-labor ratio, land-labor ratio, education and including census division fixed effects. The White-Koenker test indicates that the null-hypothesis that the residuals are homoskedastic cannot be rejected, while the Ramsey RESET test shows that we do not face an omitted variable bias problem. The VIF statistics indicate no multicollinearity problems. In general, the model fits the data well, explaining about two-thirds of the variance in labor productivity across American metropolitan areas.

$<$ Table 4> 
Turning to the main results, we find a positive and significant effect of the capital-labor ratio (elasticity of 0.75 ) and no effect of the proportion of the workforce with a bachelor's degree or higher on metropolitan labor productivity. However, our main interest lies in examining the effect of metropolitan size and structure on urban performance. In line with the existing empirical work on agglomeration, we find a positive and significant effect of urbanization externalities on metropolitan labor productivity. A doubling of metropolitan size increases metropolitan labor productivity by over $10 \%$. This is slightly higher than the consensus view that a doubling of city size increases productivity by between 3 and $8 \%$ (Rosenthal and Strange, 2004) and the average of $5.4 \%$ found by Melo et al. (2009) in a meta-analyses of such estimates.

With respect to metropolitan spatial structure, we find mixed results, in the sense that we find a positive and significant effect of the degree of polycentricity on metropolitan labor productivity, but no effect of the degree of dispersion. We had expected that dispersion would have a negative effect on labor productivity, but this is not the case. However, the positive effect of the degree of polycentricity on metropolitan labor productivity confirms our theoretical expectation. A doubling of the degree of polycentricity, increases the metropolitan labor productivity by $5.5 \%$. This means that the labor productivity in metropolitan areas in which the urban population is relatively evenly spread over multiple places in the metropolitan area leads to higher labor productivity than in metropolitan areas in which the urban population is concentrated in one large city, holding everything else constant. We will elaborate on this important finding in the concluding section. 
Comparing the OLS and TSLS estimator (Model 2 in Table 4), it can be seen that the urbanization externalities effect is over $25 \%$ less when estimated using TSLS (elasticity of 0.078 ), while the effect of the capital-labor ratio is larger. The parameter estimates of polycentricity and dispersion do not significantly differ across the models.

Examining the two interaction effects between metropolitan structure and urbanization externalities (Model 3 and 4 in Table 5), the only negative effect we found is for the interaction between metropolitan size and polycentricity on metropolitan labor productivity. The negative and significant interaction term can be interpreted as the fact that urbanization externalities are larger in monocentric cities. This confirms our theoretical assumption that polycentricity diminishes the effect of size on labor productivity. We will discuss the important theoretical implications of this finding further in the next section. Similarly, it can also be interpreted as that the benefits of polycentricity hold more for smaller regions than for large regions (in terms of population).

$<$ Table 5>

\section{Conclusion and discussion}

Recent theoretical interest of geographers has turned to post-industrial forms of urban agglomeration. The industrial image of a metropolitan area as being composed of an urban core and a rural hinterland is in many cases becoming obsolete and appears to be being replaced by increasingly polycentric metropolitan areas that 
spread over larger territories, thereby including multiple cities that together constitute a metropolitan network of cities. The 'city' is becoming a regional phenomenon and calls have been made that this should also manifest itself in the study of agglomeration economics as these seem to be associated also with wider, and more polycentric, forms of metropolitan agglomeration rather than being confined to a single urban core (Alonso, 1973; Kloosterman and Musterd, 2001; Phelps and Ozawa, 2003; Cheshire, 2006; Parr, 2008). Despite these calls, however, several of these scholars have suggested that empirical research on agglomeration externalities in relation to the regional urban systems is rather non-existent, contrary to the more local scale of polycentric cities (Lee and Gordon, 2007). An important reason for this empirical deficit is that many existing empirical analyses of agglomeration still originate from definitions of metropolitan areas that depart from a single nodal perspective. By this, we mean that the vast majority of countries defines functional urban areas as being one central city and its hinterland, thereby ignoring the possibility of having multiple core cities. Moreover, particularly in urban economics, spatial structure is hardly an issue and often approximated by general indicators such as just size or density, which, however, do not reveal much detail of the spatial structure within regions.

This paper takes up this empirical challenge by analysing how different spatial structures affect the development of agglomeration externalities in U.S. metropolitan areas in 2006 with over 250,000 inhabitants. Externalities were measured in terms of labor productivity. The widest official delimitation of metropolitan areas was used (CSAs), and these were supplemented with MSAs that do not form part of such CSAs. 
As regards spatial structure, we assumed that, next to size, two dimensions are important as these affect urban concentration within the region: 1) the monocentricity-polycentricity dimension that indicates to what extent the urban population is concentrated in one urban centre (monocentricity), or spread over multiple urban centres in a metropolitan area in a balanced way (polycentricity); and, 2) the centralization-dispersion dimension, which indicates the extent to which the metropolitan population is concentrated in centers. In addition to these indicators relating to spatial structure we controlled for the capital-labor ratio, land-labor ratio and human capital .

The empirical analysis in this paper resulted in four findings about the relationship between a region's spatial structure and its economic performance in terms of labor productivity.

1) Metropolitan areas with more dispersion do not perform worse in terms of labor productivity.

Whether a large part of the population is concentrated in urban centers or lives outside of these centers in the non-urban part of the metropolitan area was not found to influence labor productivity. Thus we found no evidence for the expectation that dispersion is harmful to labor productivity.

2) Metropolitan areas that are more polycentric show higher labor productivity. 
We found a positive and significant direct effect of the degree of polycentricity on labor productivity. The more evenly the population is spread across the different places in a metropolitan area, the higher the labor productivity in the metropolitan area. As labor productivity proxies the balance between agglomeration economies and diseconomies, we can conclude that this balance is better in the more polycentric metropolitan areas. This can be explained by the assumption that urbanisation diseconomies are less in the more polycentric areas and the idea that urbanisation economies have 'regionalized' to some extent, while 'urbanisation diseconomies' appear to be confined to the city boundaries. So, this result appears to confirm ideas that agglomeration externalities spread over larger distances, and may interact in regions where multiple urban places and hence multiple sources of agglomeration externalities are co-located. As such, it confirms that agglomeration economies need to be conceptualised in relational terms. Thus, as Phelps and Ozawa (2003) proposed, external economies are not confined to a single urban core, but instead, appear to be shared among a group of functionally linked settlements. The latter appears to be the case for the relatively more polycentric metropolitan areas. Finding 3, however, qualifies the extent to which this 'regionalization' of agglomeration economies takes place.

3) The effect of metropolitan size decreases as metropolitan areas are more polycentric

Metropolitan size tends to reflect the presence of urbanization externalities. It was found that the degree of polycentricity has an indirect effect on labor productivity as 
urbanization externalities are fewer in the more polycentric metropolitan areas. Put differently, the productivity gains of size diminish as the metropolitan area becomes more polycentric. These results are in line with the conclusion of Meijers (2008a), who found that the more polycentric a region was, the less cultural, leisure and sports amenities were present. It also confirms the doubts raised by Parr (2004; 2008) and Bailey and Turok (2001) that the magnitude of urbanization externalities in a polycentric metropolitan area is less compared to a monocentric metropolitan area. From a theoretical perspective, we cannot expect the advantages based on density, proximity and the easy and sometimes unplanned exchange of information to be equally present in a metropolitan area in which population is spread over multiple smaller cities as in one where the population is concentrated in a single large city. This result means that a collection of cities does not provide a substitute for the urbanization externalities of a single large city, even though the size of the population in both metropolitan areas is similar.

4) Polycentricity appears to be more beneficial in smaller (population) metropolitan areas

Our findings on the interaction-effect could also be interpreted as that the positive effect of having a relatively more polycentric spatial structure on labor productivity found here decreases as the population size of the metropolitan area increases. A possible reason for polycentricity being relatively more beneficial in smaller metropolitan areas is that perhaps cities in smaller polycentric metropolitan areas are 
more functionally related than those in larger polycentric metropolitan areas. This needs to be tested, however.

\section{Research agenda}

More generally, the relation between the strength and extent of functional linkages between cities in a metropolitan area and their performance as a regional urban system deserves further exploration. Also external linkages between more distant metropolitan regions require our attention. The idea that such external linkages are of great importance in explaining metropolitan performance appears to hold in particular for the largest metropolitan areas as these are the main locations for knowledge-intensive activities such as the advanced producer services and as such, the centers in the global network of information and knowledge exchange (Sassen, 1991; Hall and Pain, 2006). In this, it would be interesting to see whether agglomeration externalities are also shared between even more distant cities. Other important research issues following from our findings are whether the gap in urbanization externalities between more polycentric and more monocentric metropolitan areas is increasing or diminishing over time, whether typical agglomeration disadvantages are less severe in polycentric metropolitan areas indeed and whether the effects of spatial structure on productivity levels differ across sectors.

\section{References}

Alonso W, 1973, “Urban Zero Population Growth” Daedalus 109, 191-206 
Anas A, Arnott R, Small K A, 1998, "Urban Spatial Structure" Journal of Economic Literature 36 1426-1464

Bailey, N, Turok, I, 2001, "Central Scotland as a polycentric urban region: useful planning concept or chimera?" Urban Studies 38 697-715

Bertaud A, 2004, "The Spatial Organization of Cities: Deliberate Outcome or Unforeseen Consequence?", IURD Working Paper Series WP-2004-01, Institute of Urban \& Regional Development, Berkeley, CA

Boarnet M G, 1994, "An empirical model of intermetropolitan population and employment growth" Papers in Regional Science 73 135-152

Broersma L, Oosterhaven J, 2009 "Regional Labour Productivity in The Netherlands: Evidence of Agglomeration and Congestion Effects" Journal of Regional Science $49483-511$

Brueckner J K, 2001, "Urban Sprawl: Lessons from Urban Economics" in BrookingsWharton Papers on Urban Affairs Eds W G Gale, J Rothenberg Pack (Brookings Institution Press, Washington DC) pp 65-89

Brülhart M, Mathys N A (2009), "Sectoral Agglomeration Economies in a Panel of European Regions", Regional Science and Urban Economics 38, 348-362

Burger M J, Oort van F G, Frenken K, Knaap van der B, 2009, "Networks and Economic Agglomerations" Tijdschrift voor Economische en Sociale Geografie, $100139-144$

Burger M J, Oort van F G, Knaap van der B, 2010, "A treatise of the Geographical Scale of Agglomeration Externalities and the Modifiable Areal Unit Problem" Scienze Regionali (forthcoming).

Capello R, 2000, "The City Network Paradigm: Measuring Urban Network Externalities" Urban Studies 37 1925-1945

Capello R, Camagni R, 2000, "Beyond Optimal City Size: An Evaluation of Alternative Urban Growth Patterns" Urban Studies 37 1479-1496

Cheshire P C, 2006, "Resurgent cities, urban myths and policy hubris: what we need to know" Urban studies 43 1231-1246

Ciccone A, 2002, "Agglomeration effects in Europe" European Economic Review 46 213-227

Ciccone A, Hall R E, 1996, "Productivity and the density of economic activity" American Economic Review 86 54-70

Coe N M, Townsend A R, 1998, "Debunking the Myth of Localized Agglomerations: The Development of a Regionalized Service Economy in South-East England" Transactions of the Institute of British Geographers 23 385-404 
Combes P P, Mayer T, Thisse J F, 2008 Economic Geography: The Integration of Regions and Nations (Princeton University Press, Princeton, $\mathrm{N} J$ )

Corpataux J, Crevoisier O, 2007, "Economic theories and spatial transformations clarifying the space-time premises and outcomes of economic theories" Journal of Economic Geography 7 285-309

Florida R, Gulden T, Mellander C, 2008, "The rise of the mega-region" Cambridge Journal of Regions, Economy and Society $1459-476$

Fogarty M, Garofolo G, 1988, "Urban Spatial Structure and Productivity Growth in the Manufacturing Sector of Cities" Journal of Urban Economics 23 60-70

Frenken K, Oort van F G, Verburg T, 2007 "Related Variety, Unrelated Variety and Economic Growth" Regional Studies 41 685-697

Fujita, M, Thisse J F, Zenou Y, 1997 "On the endogenous formation of secondary employment centres in a city" Journal of Urban Economics 41 337-357.

Glaeser E L, Kahn M E, 2001, "Decentralized Employment and the Transformation of the American City", Working paper 8117, National Bureau of Economic Research, Cambridge, $M A$

Glaeser, E L, Kahn M E, 2004, "Sprawl and urban growth" in Handbook of Regional Science and Urban Economics, Vol. 4 Cities and Geography Eds J V Henderson, J-F Thisse (Elsevier Amsterdam) pp 2481-2527

Goei de B, Burger M J, Kitson M, Oort van F G, 2009, "Functional Polycentrism and Urban Network Development in the Greater South East UK: Evidence from Commuting Patterns" Regional Studies (forthcoming).

Goffette-Nagot, F, Schmitt, B, 1999, "Agglomeration economies and spatial configurations in rural areas" Environment and Planning A 31 1239-1257.

Gordon I, McCann P, 2000, "Industrial Clusters: Complexes, Agglomeration and/or Social Networks?” Urban Studies 37 513-532

Green N, 2007, "Functional Polycentricity: A Formal Definition in Terms of Social Network Analysis" Urban Studies 44 2077-2103

Hall P, 2000, "Global city-regions in the twenty-first century" in Global City Regions: Trends, Theory, Policy Ed. A J Scott (Oxford University Press, Oxford) pp 59-77

Hall P, Pain K, 2006 The polycentric metropolis: learning from mega-city regions in Europe (Earthscan, London)

Hohenberg P, Lees L, 1985 The Making of Urban Europe, 1000-1994 (Harvard University Press, Cambridge, MA).

Isard W, 1956 Location and Space Economy (MIT Press, Cambridge, MA) 
Johansson B, Quigley J M, 2004, "Agglomeration and networks in spatial economies" Papers in Regional Science 83 165-176

Kim S, 2007, "Changes in the nature of urban spatial structure in the United States, 1890-2000" Journal of Regional Science 47 273-287

Kloosterman R C, Lambregts B, 2001, "Clustering of Economic Activities in Polycentric Urban Regions: The Case of the Randstad" Urban Studies 38 717-732

Kloosterman R C, Musterd S, 2001, "The Polycentric Urban Region: Towards a Research Agenda” Urban Studies 38 623-633

Lambooy J G, 1998, "Polynucleation and Economic Development: The Randstad" European Planning Studies 6 457-466

Lee B, Gordon P, 2007, "Urban spatial structure and economic growth in US Metropolitan Areas", paper presented at the $46^{\text {th }}$ annual meeting of the Western Regional Science Association, Newport Beach, CA

Meijers E J, 2005, "Polycentric Urban Regions and the Quest for Synergy: Is a Network of Cities More than the Sum of the Parts?" Urban Studies 42 765-781

Meijers E J, 2008a, "Summing small cities does not make a large city: Polycentric Urban Regions and the provision of Cultural, Leisure and Sports Amenities" Urban Studies 45 2323-2342

Meijers E J, 2008b, “Measuring polycentricity and its promises" European Planning Studies 16 1313-1323

Melo P C, Graham DJ, Noland R B, 2009, "A meta-analysis of estimates of urban agglomeration economies" Regional Science and Urban Economics $39332-342$

Nordregio et alia, 2004, ESPON 1.1.1: Potentials for polycentric development in Europe, Project report, Nordregio/ESPON Monitoring Committee, Stockholm/Luxembourg

Office of Management and Budget (OMB), 2000, Standards for defining Metropolitan and Micropolitan Regions, Federal Register, 65, No.249

Oort van F G, 2004, Urban Growth and Innovation, Spatially Bounded Externalities in the Netherlands (Ashgate, Aldershot)

Oort van F G, Burger M J, Raspe O, 2010, "On the Economic Foundation of the Urban Network Paradigm. Spatial Integration, Functional Integration and Economic Complementarities within the Dutch Randstad" Urban Studies (forthcoming)

Parr J B, 2002, “Agglomeration economies: ambiguities and confusions" Environment and Planning A 34 717-731 
Parr J B, 2004, "The Polycentric Urban Region: A Closer Inspection" Regional Studies $38231-240$

Parr J B, 2005, “Perspectives on the City-Region” Regional Studies 39 555-566

Parr J B, 2008, "Cities and regions: problems and potentials" Environment and Planning A 40 3009-3026

Phelps N A, Fallon R J, Williams C L, 2001, "Small Firms, Borrowed Size and the UrbanRural Shift" Regional Studies 35 613-624

Phelps, N A, Ozawa T, 2003, "Contrasts in agglomeration: proto-industrial, industrial and post-industrial forms compared" Progress in Human Geography 27 583-604

Richardson H W, 1995, "Economies and diseconomies of agglomeration" in Urban agglomeration and economic growth Ed. H Giersch (Springer, Berlin) pp 123-155

Rosenthal S S, Strange W C, 2004, "Evidence on the nature and sources of agglomeration economies" in Handbook of Regional Science and Urban Economics, Vol. 4 Cities and Geography Eds J V Henderson, J-F Thisse (Elsevier Amsterdam) pp 2119-2171

Sassen, S, 1991, The Global City: New York, London, Tokyo (Princeton University Press, Princeton, NJ)

Sassen S, 2007, “Megaregions: Benefits Beyond Sharing Trains and Parking Lots?” in The Economic Geography of Mega-Regions Ed. K S Goldfeld, (The Policy Research Institute for the Region, Princeton, NJ) pp 59-83

Scott A J, 1988 Metropolis: From the Division of Labor to Urban Form (University of California Press, Berkeley and Los Angeles)

Scott A J, 2000, "Economic geography: the great half-century" Cambridge Journal of Economics 24 483-504

Siegel P, Johnson T, Alwang J, 1995, "Regional Economic Diversity and Diversification" Growth and Change 26 261-284

Stock J H, Yogo M, 2005, "Testing for weak instruments in linear IV regression" in Identification and Inference for Econometric Models: Essays in Honor of Thomas Rothenberg Eds D W K Andrews, J H Stock, (Cambridge University Press, Cambridge) pp 80-108

Storper M, 1997 The Regional World: Territorial Development in a Global Economy (Guilford Press, London and New York)

Stover J F, 1961 American Railroads (The University of Chicago Press, Chicago)

Turok I, Bailey N, 2004, "The Theory of Polynuclear Urban Regions and its Application to Central Scotland" European Planning Studies 12 371-389 
Transportation Research Board, 2002 Costs of Sprawl - 2000 (National Academy Press, Washington, DC)

Woolridge J M, 2006 Introductory Econometrics: A Modern Approach (Thomson South-Western Educational Publishing, Mason, $\mathrm{OH}$ ) 


\section{Notes}

${ }^{1}$ Only considering incorporated places of at least 5,000 inhabitants in 2006. In cases where the second largest incorporated place in the metropolitan region did not meet this threshold, we used its actual size in order to be able to calculate a slope.

${ }^{2}$ Following common definitions of such regions (see Kloosterman and Musterd, 2001; Parr, 2004; Meijers, 2005), although for a definite categorization we require more knowledge on the level of specialization and the level of interaction.

${ }^{3}$ Using census region dummies (covering four broad geographical regions) yielded similar empirical results.

${ }^{4}$ The Anderson canonical correlation statistic is significant in all four specifications, meaning that the instruments used in these specifications are adequate to identify the equation. The Cragg-Donald F-statistic tests whether we face a weak-instrument problem. A set of instruments is defined as weak if the bias of the TSLS estimator, relative to the bias of the OLS estimator, exceeds the threshold of $10 \%$ (Stock and Yogo, 2005) at the $5 \%$ confidence level. As can be obtained from Table 3, this is the case for all specifications as the value of the Cragg-Donald F-statistic exceeds the critical values provided by Stock and Yogo (2005). These results are reinforced by the Shea partial $R^{2}$ statistic, which is reasonably high for all specifications. In particular, metropolitan size appears to be well instrumented.

${ }^{5}$ In this, it is tested whether the instruments for metropolitan size and spatial structure are uncorrelated with the disturbance term. As these overidentification test statistics were non-significant for all four specifications, we cannot reject the null hypothesis that the instruments are uncorrelated with the disturbance term of the dependent variable and can be considered valid. 
Figure 1. Dimensions of regional urban form.
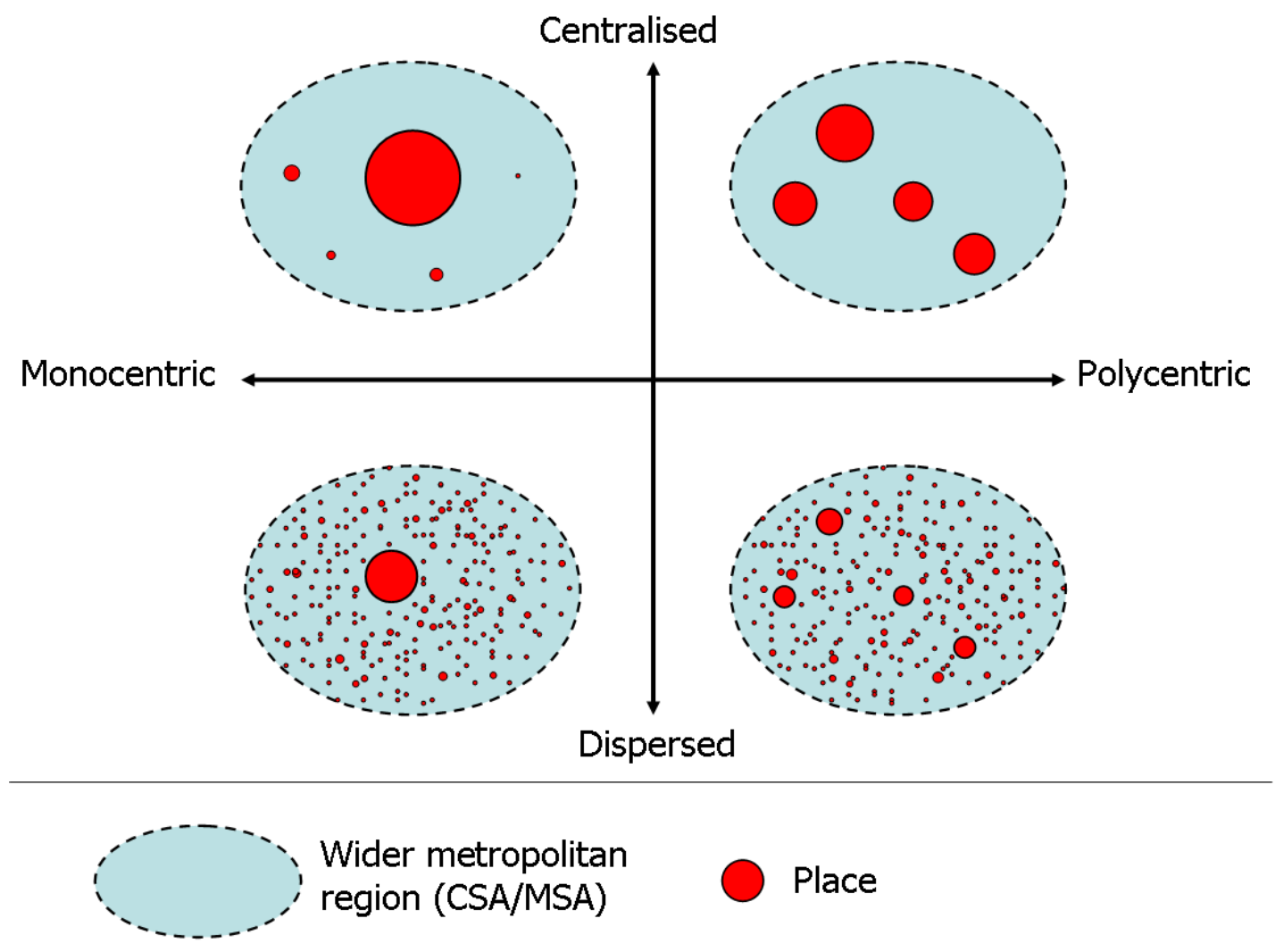
Figure 2. Rank-size distributions to measure mono/polycentricity.
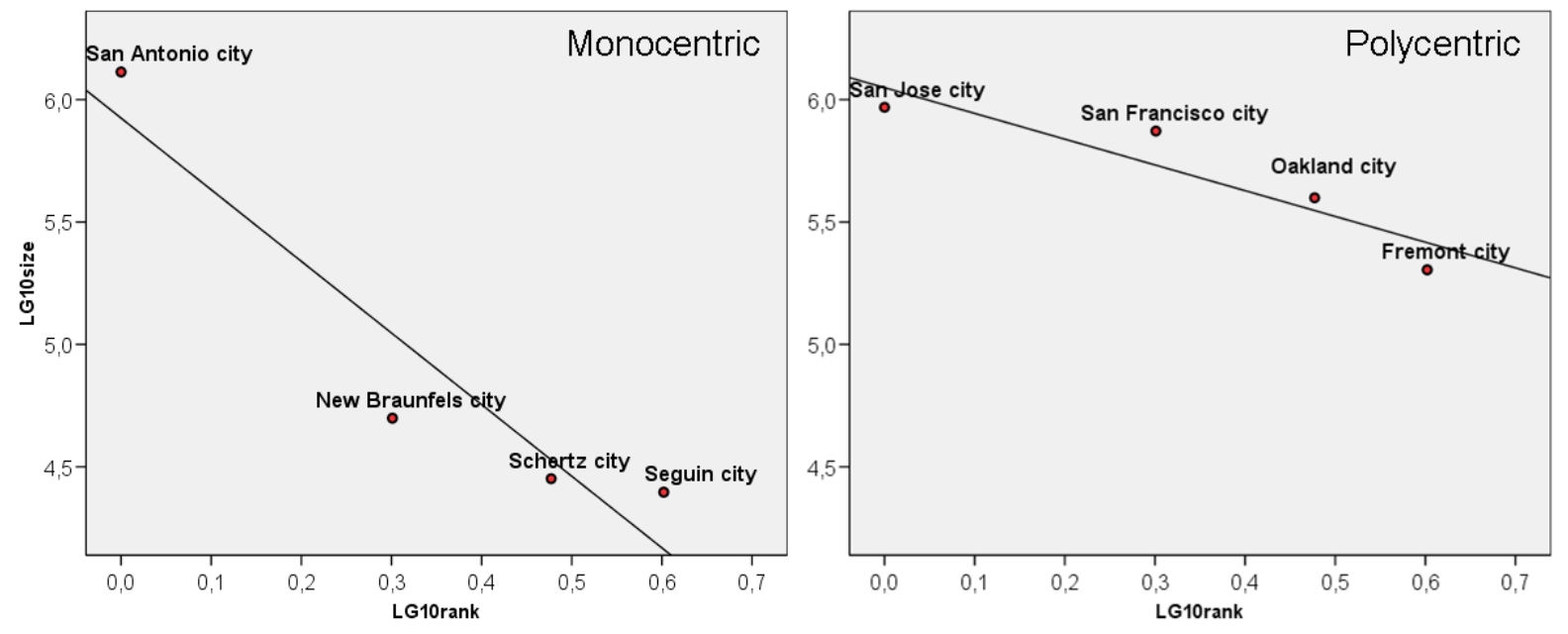
Table 1. Most monocentric, polycentric, centralised and dispersed metropolitan regions in the U.S.

\begin{tabular}{|l|l|l|l|l|}
\hline Rank & Most monocentric & Most polycentric & Most centralised & Most dispersed \\
\hline 1 & Lincoln, NE & Midland-Odessa, TX & El Paso, TX & $\begin{array}{l}\text { Greenville- } \\
\text { Spartanburg- } \\
\text { Anderson, SC }\end{array}$ \\
\hline 2 & Tallahassee, FL & $\begin{array}{l}\text { Santa Barbara- } \\
\text { Santa Maria, CA }\end{array}$ & Lincoln, NE & $\begin{array}{l}\text { Portland-Lewiston- } \\
\text { South Portland, ME }\end{array}$ \\
\hline 3 & Jacksonville, FL & $\begin{array}{l}\text { Johnson City - } \\
\text { Kingsport - Bristol } \\
\text { (Tri-cities), TN-VA }\end{array}$ & $\begin{array}{l}\text { Phoenix-Mesa- } \\
\text { Scottsdale, AZ }\end{array}$ & $\begin{array}{l}\text { Columbia } \\
\text { Newberry, SC }\end{array}$ \\
\hline 4 & El Paso, TX & $\begin{array}{l}\text { Salt Lake City- } \\
\text { Ogden-Clearfield, } \\
\text { UT }\end{array}$ & $\begin{array}{l}\text { San Diego-Carlsbad- } \\
\text { San Marcos, CA }\end{array}$ & $\begin{array}{l}\text { Pittsburgh-New } \\
\text { Castle, PA }\end{array}$ \\
\hline 5 & San Antonio, TX & $\begin{array}{l}\text { Greenville- } \\
\text { Spartanburg- } \\
\text { Anderson, SC }\end{array}$ & Midland-Odessa, TX & $\begin{array}{l}\text { Youngstown- } \\
\text { Warren-East } \\
\text { Liverpool, OH-PA }\end{array}$ \\
\hline
\end{tabular}


Table 2. Descriptive Statistics of Variables ( $\mathrm{N}=113)$

\begin{tabular}{|l|c|c|c|c|}
\hline & Mean & Std. dev. & Minimum & Maximum \\
\hline Labor Productivity (In) & 11.29 & 0.197 & 10.70 & 11.85 \\
\hline Capital-Labor Ratio (In) & 11.93 & 0.106 & 11.73 & 12.31 \\
\hline Land-Labor Ratio (In) & -3.661 & 0.732 & -5.620 & -1.671 \\
\hline Education per Worker (In) & -0.621 & 0.404 & -1.650 & 0.418 \\
\hline Metropolitan Size (In) & 13.68 & 0.998 & 12.43 & 16.89 \\
\hline Polycentricity (In) & -0.573 & 0.554 & -1.636 & 2.291 \\
\hline Dispersion (In) & -0.769 & 0.425 & -2.144 & -0.124 \\
\hline New England & 0.027 & 0.161 & 0 & 1 \\
\hline Middle Atlantic & 0.071 & 0.258 & 0 & 1 \\
\hline East North Central & 0.177 & 0.383 & 0 & 1 \\
\hline West North Central & 0.088 & 0.285 & 0 & 1 \\
\hline South Atlantic & 0.159 & 0.368 & 0 & 1 \\
\hline East South Central & 0.177 & 0.383 & 0 & 1 \\
\hline West South Central & 0.071 & 0.258 & 0 & 1 \\
\hline Mountain & 0.088 & 0.285 & 0 & 1 \\
\hline Pacific & 0.142 & 0.350 & 0 & 1 \\
\hline
\end{tabular}


Table 3. First stage results of TSLS regressions on metropolitan labor productivity

\begin{tabular}{|c|c|c|c|c|}
\hline & $\begin{array}{c}\text { Metropolitan } \\
\text { Size }\end{array}$ & Polycentricity & Dispersion & All \\
\hline Instruments & $\begin{array}{l}\text { Population ‘50 } \\
\text { Railroad }\end{array}$ & $\begin{array}{l}\text { Polycentricity '50 } \\
\text { Railroad }\end{array}$ & $\begin{array}{l}\text { Dispersion '50 } \\
\text { Agr. land use }\end{array}$ & $\begin{array}{l}\text { Population '50 } \\
\text { Polycentricity '50 } \\
\text { Dispersion '50 } \\
\text { Railroad } \\
\text { Agr. land use }\end{array}$ \\
\hline \multicolumn{5}{|l|}{ Relevance } \\
\hline $\begin{array}{l}\text { Anderson canon. } \\
\text { corr. }\end{array}$ & $79.28 * *$ & $44.63^{* *}$ & $35.13 * *$ & $36.89 * *$ \\
\hline $\begin{array}{l}\text { Cragg-Donald F- } \\
\text { test }\end{array}$ & $114.05^{* *}$ & $31.66 * *$ & $22.11^{*}$ & $9.31 * *$ \\
\hline $\begin{array}{l}\text { Critical value } C D \\
\text { (10\% relative bias) }\end{array}$ & 19.93 & 19.93 & 19.93 & 6.06 \\
\hline \multicolumn{5}{|l|}{ Shea Partial $\mathrm{R}^{2}$} \\
\hline $\begin{array}{l}\text { - Metropolitan } \\
\text { size }\end{array}$ & 0.70 & & & 0.75 \\
\hline - Polycentricity & & 0.40 & & 0.43 \\
\hline - Dispersion & & & 0.31 & 0.33 \\
\hline \multicolumn{5}{|l|}{ Validity } \\
\hline Sargan statistic & 0.29 & 0.08 & 0.00 & 1.00 \\
\hline Basmann statistic & 0.25 & 0.07 & 0.00 & 0.86 \\
\hline \multicolumn{5}{|l|}{ Exogeneity } \\
\hline $\begin{array}{l}\text { Wu-Hausman F- } \\
\text { test }\end{array}$ & $4.78^{*}$ & 0.71 & 0.02 & 1.85 \\
\hline $\begin{array}{l}\text { Durbin-Wu- } \\
\text { Hausman } \\
\text { Square test }\end{array}$ & $5.31 *$ & 0.83 & 0.02 & 6.24 \\
\hline Observations & 113 & 113 & 113 & 113 \\
\hline Regressors & 14 & 14 & 14 & 14 \\
\hline Instruments & 15 & 15 & 15 & 16 \\
\hline $\begin{array}{l}\text { Excluded } \\
\text { Instruments }\end{array}$ & 2 & 2 & 2 & 5 \\
\hline
\end{tabular}


Table 4: OLS and TSLS on Metropolitan Labor Productivity (2006)

\begin{tabular}{|c|c|c|}
\hline & $\begin{array}{l}\text { Model } 1 \\
\text { OLS }\end{array}$ & $\begin{array}{l}\text { Model } 2 \\
\text { TSLS }^{\mathrm{a}}\end{array}$ \\
\hline Intercept & $11.36(.110)^{* *}$ & $11.28(.110)^{* *}$ \\
\hline Capital-Labor Ratio (In) & $0.754(.232)^{* *}$ & $0.843(.222)^{* *}$ \\
\hline Land-Labor Ratio (In) & $0.013(.032)$ & $-0.012(.032)$ \\
\hline Education per Worker (In) & $-0.007(.050)$ & $-0.010(.047)$ \\
\hline Metropolitan Size (In) & $0.107(.020)^{* *}$ & $0.078(.023)^{* *}$ \\
\hline Polycentricity (In) ${ }^{b}$ & $0.055(.023)^{*}$ & $0.051(.022)^{*}$ \\
\hline Dispersion $(\ln )^{c}$ & $0.024(.039)$ & $0.030(.036)$ \\
\hline Census division dummies & YES & YES \\
\hline Number of Observations & 113 & 113 \\
\hline F-statistic & 13.48 & 12.01 \\
\hline $\begin{array}{l}\mathrm{R}^{2}(\mathrm{OLS}) / \\
\text { Centered } \mathrm{R}^{2}(\mathrm{TSLS})\end{array}$ & 0.66 & 0.65 \\
\hline Root MSE & 0.12 & 0.12 \\
\hline $\begin{array}{l}\text { White-Koenker (OLS) / } \\
\text { Pagan-Hall test (TSLS) }\end{array}$ & 22.7 & 19.8 \\
\hline Ramsey RESET test & 0.83 & 0.03 \\
\hline \multicolumn{3}{|c|}{$\begin{array}{l}{ }^{*} \mathrm{p}<0.01,{ }^{*} \mathrm{p}<0.05 \\
\text { Standard errors between parentheses; all non-dummy variables are mean-centered } \\
{ }^{\mathrm{a}} \text { Instruments used in the first stage of the regression for the endogenous variable } \\
\text { metropolitan population } \\
{ }^{\mathrm{b}} \text { The higher the value, the more polycentric. The lower the value, the more } \\
\text { monocentric, } \\
{ }^{\mathrm{c}} \text { The higher the value, the more dispersed. The lower the value, the more centralizec }\end{array}$} \\
\hline
\end{tabular}


Table 5: OLS and 2SLS on Metropolitan Labor Productivity (2006) - Interaction Effects

\begin{tabular}{|c|c|c|}
\hline & $\begin{array}{l}\text { Model } 3 \\
\text { OLS }\end{array}$ & $\begin{array}{l}\text { Model } 5 \\
\text { TSLS }^{\mathrm{a}}\end{array}$ \\
\hline Intercept & $11.33(.110)^{* *}$ & $11.26(.108) * *$ \\
\hline Capital-Labor Ratio (In) & $0.752(.229)^{* *}$ & $0.824(.216)^{* *}$ \\
\hline Land-Labor Ratio (In) & $0.002(.031)$ & $-0.018(.031)$ \\
\hline Education per Worker (In) & $0.015(.049)$ & $0.015(.045)$ \\
\hline Metropolitan Size (In) & $0.094(.021)^{* *}$ & $0.072(.023)^{* *}$ \\
\hline Polycentricity (In) & $0.037(.023)$ & $0.033(.022) \#$ \\
\hline Dispersion (In) & $0.038(.039)$ & $0.047(.037)$ \\
\hline $\begin{array}{l}\text { Metropolitan } \\
\text { Size*Polycentricity }\end{array}$ & $-0.059(.021)^{* *}$ & $-0.063(.020)^{* *}$ \\
\hline Metropolitan Size*Dispersion & $-0.008(.024)$ & $-0.016(.023)$ \\
\hline Census division dummies & YES & YES \\
\hline Number of Observations & 113 & 113 \\
\hline F-statistic & 13.48 & 12.11 \\
\hline $\begin{array}{l}\mathrm{R}^{2}(\mathrm{OLS}) / \\
\text { Centered } \mathrm{R}^{2}(\mathrm{TSLS})\end{array}$ & 0.68 & 0.68 \\
\hline Root MSE & 0.12 & 0.11 \\
\hline $\begin{array}{l}\text { White-Koenker (OLS) / } \\
\text { Pagan-Hall test (TSLS) }\end{array}$ & 21.11 & 20.32 \\
\hline Ramsey RESET test & 0.07 & 1.09 \\
\hline \multicolumn{3}{|c|}{$\begin{array}{l}\text { **p<0.01, }{ }^{*} \mathrm{p}<0.05 \\
\text { Standard errors between parentheses; all non-dummy variables are mean-centered } \\
\text { a Instruments used in the first stage of the regression for the endogenous variable } \\
\text { metropolitan population }\end{array}$} \\
\hline
\end{tabular}




\section{Appendix A. Selection of metropolitan regions.}

In principle, all CSAs as well as MSAs not part of a CSA with a total population of over 250,000 inhabitants in 2006 located in the U.S. continental states were included in the analysis. Metropolitan areas are defined by the U.S. Office of Management and Budget (OMB), and the latest revised version (2007) of the 2000 definitional standards was used. An MSA contains a core urban area with a population of 50,000 or more. It consists of one or more counties and includes the counties containing the core urban area, as well as any adjacent counties of which more than $25 \%$ of employed residents work in the urban core. MSAs that are adjacent may be joined in order to form a Combined Statistical Area if the employment interchange is at least 25. Adjacent MSAs that have an employment interchange measure of at least 15 and less than 25 are combined if local opinion favors combination (OMB, 2000). There are also micropolitan areas that contain an urban core with a population of at least 10,000 but less than 50,000 . These are not considered here, unless they form part of a CSA that is furthermore composed of at least one MSA.

Some regions had to be left out for other reasons:

1) CSAs are composed of metropolitan statistical areas and/or micropolitan statistical areas. Often, data was not available for micropolitan areas. In a limited number of cases, this meant that no reliable data for the CSA could be retrieved. There were a couple of CSAs, where more than $20 \%$ of their population was located in a micropolitan statistical area, which were left out for this reason. These were Charlotte-Gastonia-Salisbury, NC-SC; Fort Wayne Huntington- Auburn, IN; and, Lexington-Fayette--Frankfort--Richmond, KY. 
2) New Orleans was left out as the data appeared biased as a result of Hurricane Katrina.

As argued in the text, polycentric conurbations had to be left out. These include: Albany-Schenectady-Amsterdam, NY; Charleston-North Charleston, SC; Dallas-Fort Worth, TX; Davenport-Moline-Rock Island, IA-IL; Fayetteville-Springdale-Rogers, ARMO; Hartford-West Hartford-East Hartford, CT; McAllen-Edinburg-Mission, TX; MiamiFort Lauderdale-Miami Beach, FL; Minneapolis-St. Paul- St. Cloud, MN-WI; Palm BayMelbourne-Titusville, FL; Provo-Orem, UT; Sarasota-Bradenton-Punta Gorda, FL; Scranton-Wilkes-Barre, PA; Tampa-St. Petersburg-Clearwater, FL; Virginia BeachNorfolk-Newport N., VA-NC. 


\section{Publications in the ERIM Report Series Research* in Management}

\section{ERIM Research Program: "Organizing for Performance"}

\section{9}

On the Specification of the Gravity Model of Trade: Zeros, Excess Zeros and Zero-Inflated Estimation

Martijn J. Burger, Frank G. van Oort, and Gert-Jan M. Linders

ERS-2009-003-ORG

http://hdl.handle.net/1765/14614

The Current State of Research on Networks in China's Business System

Johannes Meuer and Barbara Krug

ERS-2009-007-ORG

http://hdl.handle.net/1765/14842

Encountered Problems and Outcome Status in Nascent Entrepreneurship

A. Marco van Gelderen, B. Pankaj Patel, and A. Roy Thurik

ERS-2009-008-ORG

http://hdl.handle.net/1765/14913

The Ethics of Organizations: A Longitudinal Study of the U.S. Working Population

Muel Kaptein

ERS-2009-018-ORG

http://hdl.handle.net/1765/15405

From Symbolic to Substantive Documents: When Business Codes of Ethics Impact Unethical Behavior in the Workplace Muel Kaptein

ERS-2009-021-ORG

http://hdl.handle.net/1765/15909

Knowledge Management as a Strategic Tool to Foster Innovativeness of SMEs

Haibo Zhou, and Lorraine Uhlaner

ERS-2009-025-ORG

http://hdl.handle.net/1765/15913

Knowledge Management in the SME and its Relationship to Strategy, Family Orientation and Organization Learning Haibo Zhou, and Lorraine Uhlaner

ERS-2009-026-ORG

http://hdl.handle.net/1765/15914

Defining Respectful Leadership: What it is, how it can be measured, and another glimpse at what it is related to Niels van Quaquebeke, and Tilman Eckloff ERS-2009-027-ORG

http://hdl.handle.net/1765/15942

Blue Ocean versus Competitive Strategy: Theory and Evidence

Andrew Burke, André van Stel, and Roy Thurik

ERS-2009-030-ORG

http://hdl.handle.net/1765/16037

Pattern matching

Tony Hak and Jan Dul

ERS-2009-034-ORG

http://hdl.handle.net/1765/16203

Replication

Tony Hak and Jan Dul

ERS-2009-035-ORG

http://hdl.handle.net/1765/16204 
Theory-Building With Cases

Tony Hak and Jan Dul

ERS-2009-036-ORG

http://hdl.handle.net/1765/16205

Theory-Testing With Cases

Tony Hak and Jan Dul

ERS-2009-036-ORG

http://hdl.handle.net/1765/16206

Functional Polycentrism and Urban Network Development in the Greater South East UK: Evidence from Commuting Patterns, 1981-2001

B. de Goei, M.J. Burger, F.G van Oort, and M. Kitson

ERS-2009-038-ORG

http://hdl.handle.net/1765/16213

On the Economic Foundation of the Urban Network Paradigm: Spatial Integration, Functional Integration and Economic Complementarities within the Dutch Randstad

F.G. van Oort, M.J. Burger, and O. Raspe

ERS-2009-039-ORG

http://hdl.handle.net/1765/16214

Gender Pay Differences in the European Union: Do Higher Wages Make Up For Discrimination?

Erik Canton and Ingrid Verheul

ERS-2009-041-ORG

http://hdl.handle.net/1765/16215

What do We Know about Social Entrepreneurship: An Analysis of Empirical Research

Brigitte Hoogendoorn, Enrico Pennings, and Roy Thurik

ERS-2009-044-ORG

http://hdl.handle.net/1765/16558

Developing Innovative Competences in an Emerging Business System: New Private Enterprises in Hangzhou's Software Industry

Mark Greeven and Zhao Xiaodong

ERS-2009-045-ORG

http://hdl.handle.net/1765/16599

From Inaction to External Whistleblowing: The Influence of the Ethical Culture of Organizations on Employee Responses to Observed Wrongdoing

Muel Kaptein

ERS-2009-047-ORG

http://hdl.handle.net/1765/16600

What Turns Knowledge into Innovative Products? The Role of Entrepreneurship and Knowledge Spillovers

Joern H. Block, Roy Thurik, and Haibo Zhou

ERS-2009-049-ORG

http://hdl.handle.net/1765/16769

The X-Factor: On the Relevance of Implicit Leadership and Followership Theories for Leader-Member Exchange (LMX)

Agreement

Suzanne van Gils, Niels van Quaquebeke, and Daan van Knippenberg

ERS-2009-055-ORG

http://hdl.handle.net/1765/17429

Entrepreneurial Finance in France: The Persistent Role of Banks

Sylvie Cieply and Marcus Dejardin

ERS-2009-056-ORG

http://hdl.handle.net/1765/17430 
Spatial Structure and Productivity in U.S. Metropolitan Areas

Evert Meijers and Martijn Burger

ERS-2009-057-ORG

http://hdl.handle.net/1765/17431

* A complete overview of the ERIM Report Series Research in Management: https://ep.eur.nl/handle/1765/1

ERIM Research Programs:

LIS Business Processes, Logistics and Information Systems

ORG Organizing for Performance

MKT Marketing

F\&A Finance and Accounting

STR Strategy and Entrepreneurship 